\title{
Hommes et Troupeaux en Montagne. La question pastorale en Ariège (in French) [People and livestock in the mountains: the pastoral question in Ariège]
}

\author{
Sarah Robinson
}

\author{
Book details \\ Eychenne, C \\ Hommes et Troupeaux en Montagne. La question pastorale en Ariège. \\ Paris: L'Harmattan; 2006. \\ 320 pages, ISBN 2-296-00324-9
}

Keywords: Europe; Pyrenees; Mountain livestock; Pastoralism; Pyrenees; France; Land tenure

This book is a monograph on socio-cultural aspects of pastoralism in the Pyrenean departement of Ariège in France. It was published in French in 2006 and is not translated into English; however, it merits attention as a detailed and carefully constructed picture of modern pastoralism in a large mountainous region of Europe.

The book explores pastoralism primarily from the point of view of livestock managers and owners. The author worked in 16 large summer pastures covering a third of the departement and used an anthropological approach, conducting in-depth interviews mainly with livestock managers but also with hired shepherds, technicians and administrators. Direct quotes from the livestock managers are used very effectively to illustrate points made in the text.

A historical section sets the scene and explains the changes in property rights systems before and after the French revolution of the eighteenth century which underpins land use today. The author then describes the recent development of pastoralism in Ariège, covering access rights to summer pastures, the social organisation of grazing and interactions between livestock managers and the state, local authorities and technical advisors. She explores the construction of social norms and ideas

Correspondence: s.robinson@imperial.ac.uk

Division of Ecology and Evolution, Imperial College London, London SW7 2AZ, UK

\section{Springer}

(c) 2015 Robinson; licensee Springer. This is an Open Access article distributed under the terms of the Creative Commons Attribution License (http://creativecommons.org/licenses/by/4.0), which permits unrestricted use, distribution, and reproduction in any medium, provided the original work is properly credited. within pastoralist groups and the reaction of livestock managers to modern external factors such as tourism, wildlife protection and the re-introduction of bears. She finds that although livestock raising and the people conducting it are often caricatured as backward and resistant to change, much about current pastoralism is also modern and dynamic.

The book benefits from judicious use of statistics and cadastral materials. Trends in livestock numbers, average sizes of holdings, and age and income of livestock owners are used to illustrate factors behind behavioural change and to compare changes in Ariège with those in other parts of the Pyrenees. We learn much that is surprising about the recovery of pastoralism (in terms of livestock numbers) since the 1970s and about the impacts of subsidies on grazing systems, pastoralist economics and the self-image of livestock managers.

A particular focus of the book is pastoral access rights and social organisation of grazing on the commons in Ariège. Grazing land is almost entirely held in common use, owned either by the forestry commission or communes (parishes). Even some pasture in private ownership is held by groups, in 'indivision'. The book describes the transition from regulation of pasture access by representatives of administrative entities (such as mayors and parish councils) to the user groups themselves, for whom geographic provenance has declined in importance. This is a natural 
consequence of specialisation and professionalisation of livestock raising but is also influenced by specific government policies aimed at transferring management to land users. Yet even within these user groups, history, tradition and the geographic residence of members still play a role. Particularly interesting are the mechanisms regulating access to pastures by individuals, mechanisms which vary between groups. Formal use rights based on residence are combined with criteria such as age, family history and personal connections, to decide who may use the pasture, the number of livestock they may graze, and how much must be paid to use the resource.

Pastoralist perceptions of and reaction to technical recommendations on management of vegetation, breeding and livestock health are discussed at length. However, it is not always clear to what extent scientific evidence and pastoralists' observations correspond. Some references to scientific literature, particularly on pasture condition and vegetation change, would have been welcome.

A clear theme which emerges is the struggle by pastoralists to construct a professional identity based on their principal source of pride - production of high-quality produce in a mountain environment, to counter their image as backward recipients of subsidies for environmental maintenance. This struggle is at the heart of pastoralism in many remote regions of Europe and is sensitively captured in this excellent book.

Both the book itself and its extensive bibliography are a reminder of the rich literature on European pastoralism existing in French. This book in particular deserves to be translated into English and to reach a wider audience.

Competing interests

The author declares that she has no competing interests.

Received: 20 January 2015 Accepted: 25 January 2015

Published online: 10 February 2015
Submit your manuscript to a SpringerOpen ${ }^{\circ}$ journal and benefit from:

- Convenient online submission

- Rigorous peer review

- Immediate publication on acceptance

- Open access: articles freely available online

- High visibility within the field

- Retaining the copyright to your article

Submit your next manuscript at springeropen.com 